\title{
Step-by-Step Assembled Enzyme-Polymer-Carbon Nanotubes for Solution-Processed Bioreactive Composites
}

\author{
Hsiu-Pen Lin, ${ }^{\dagger, \perp}$ Jun Akimoto, ${ }^{\dagger}$ Yaw-Kuen Li, ${ }^{*}, \perp, \S$ Yoshihiro Ito, ${ }^{*},{ }^{\dagger}, \#$ and Masuki \\ Kawamoto ${ }^{*}, \dagger, \#, \|$
}

$\dagger$ Emergent Bioengineering Materials Research Team, RIKEN Center for Emergent Matter Science, 2-1 Hirosawa, Wako, Saitama 351-0198, Japan

$\perp$ Department of Applied Chemistry, National Chiao Tung University, 1001 University Road, Hsinchu 300, Taiwan

$\S$ Center for Emergent Functional Matter Science, National Chiao Tung University, Hsinchu 30010, Taiwan;

\#Nano Medical Engineering Laboratory, RIKEN Center for Pioneering Research, 2-1 Hirosawa, Wako, Saitama 351-0198, Japan

\|Graduate School of Science and Engineering, Saitama University, 255 Shimo-Okubo, Sakura-ku, Saitama 338-8570, Japan

*Corresponding author. E-mail: nctuyk1@g2.nctu.edu.tw, y-ito@riken.jp, mkawamot@riken.jp

\section{Table of contents}

\begin{tabular}{|l|l|}
\hline 1. Synthesis & $\mathrm{S}-2$ \\
1.1. Materials & $\mathrm{S}-2$ \\
1.2. Synthesis of polymers & $\mathrm{S}-2$ \\
2. Characterization & $\mathrm{S}-5$ \\
3. Determination of the loading ratio of $\mathbf{O s}\left(\mathbf{b p y} \mathbf{~}_{2} \mathbf{C l}_{\mathbf{2}}\right.$ in PVImQOs & $\mathrm{S}-6$ \\
4. Absorption spectra of polymers and an Os complex in water & $\mathrm{S}-7$ \\
5. Aqueous dispersion behavior of SWCNTs & $\mathrm{S}-8$ \\
6. Preparation of $\mathrm{GO}_{\mathrm{x}} / \mathbf{P V I m Q O s} / \mathrm{SWCNTs}$ composites on the working \\
electrode & $\mathrm{S}-9$ \\
7. Determination of the loading amount of $\mathrm{GO}_{\mathrm{x}}$ using the Bradford assay \\
8. Electrochemical responses of enzyme/polymer/SWCNTs composites \\
8.1. Sample preparation & $\mathrm{S}-10$ \\
8.2. Experimental conditions & $\mathrm{S}-11$ \\
8.3. Electrochemical responses & $\mathrm{S}-11$ \\
9. Spectroscopic characterization & $\mathrm{S}-11$ \\
9.1. ${ }^{1} \mathrm{H}-\mathrm{NMR}$ spectra & $\mathrm{S}-12$ \\
9.2. ${ }^{13} \mathrm{C}-\mathrm{NMR}$ spectra & $\mathrm{S}-15$ \\
10. Supplementary references & $\mathrm{S}-15$ \\
& $\mathrm{~S}-17$ \\
& $\mathrm{~S}-19$ \\
\hline
\end{tabular}




\section{Synthesis}

\subsection{Materials}

Unless otherwise noted, compounds and solvents were purchased from commercial suppliers and used without further purification. Single-walled carbon nanotubes (SWCNTs; $(6,5)$ chirality produced by the CoMoCAT method, $\geq 95 \%$ carbon basis ( $\geq 99 \%$ as CNTs), $0.7-0.9 \mathrm{~nm}$ in diameter) and ammonium hexachloroosmate(IV) were purchased from Sigma-Aldrich Co., Ltd. (St. Louis, MO, USA). Glucose oxidase $\left(\mathrm{GO}_{\mathrm{x}}\right.$; from Aspergillus niger (EC 1.1.3.4, 190 units $\left.\mathrm{mg}^{-1}\right)$, Bovine Serum Albumin (BSA; $98 \%$ purity by electrophoresis, fatty acid free) 2,2'-bipyridyl, ethylene glycol, 2,2'azobis(isobutyronitrile), chitosan, glucose, disodium hydrogen phosphate, sodium dihydrogen phosphate, the Bradford reagent, and toluene were purchased from Wako Pure Chemical Industries Ltd. (Osaka, Japan). 1-Vinylimidazole was purchased from Alfa Aesar (Ward Hill, MA, USA). 2-(2-Chloroethoxy)ethanol was purchased from Tokyo Chemical Industry Co., Ltd. (TCI; Tokyo, Japan). Acetic acid and diethyl ether were purchased from Junsei Chemical Co., Ltd. (Tokyo, Japan). Lactate oxidase (LO from Microorganism (EC 1.1.3.2, 85.6 units $\mathrm{mg}^{-1}$ ) was purchased from Toyobo Corp. (Osaka, Japan). Deuterium water was purchased from Cambridge Isotope Laboratories Inc. (Andover, MA, USA). Cola (Coca-Cola, sugar content: $0.113 \mathrm{~g} \mathrm{~mL}^{-1}$ ) and diet cola (Coca-Cola Zero Sugar, sugar content: $0 \mathrm{~g} \mathrm{~mL}^{-1}$ ) were purchased from Coca-Cola (Japan) Company, Ltd. (Tokyo, Japan). Because of confidential data, we could not get information about a concentration of glucose in cola. A silicon substrate was purchased from Nilaco Co., Ltd. (size: $100 \mathrm{~mm} \times 100 \mathrm{~mm}$, thickness: $0.5 \mathrm{~mm},(100)$ orientation, resistance: $<0.02 \Omega \mathrm{cm}$, Tokyo, Japan).

\subsection{Synthesis of polymers}

1-Vinylimidazole. We used this chemical as a monomer for synthesis of poly(1vinylimidazole) without purification. ${ }^{1} \mathrm{H}-\mathrm{NMR}\left(400 \mathrm{MHz}, \mathrm{D}_{2} \mathrm{O}\right): \delta=4.81$ (dd, $1 \mathrm{H}, J=$ $8.8 \mathrm{~Hz}, 1.2 \mathrm{~Hz}, \mathrm{CH}_{2} \mathrm{CH}$-imidazole), 5.25 (dd, $1 \mathrm{H}, J=15.6 \mathrm{~Hz}, 1.6 \mathrm{~Hz}, \mathrm{CH}_{2} \mathrm{CH}-$ imidazole), 6.83-6.89 (m, 2H, $\mathrm{CH}_{2} \mathrm{CH}$-imidazole and aromatic ring), 7.23 (dd, 1H, $J=$ $2.8 \mathrm{~Hz}, 2.8 \mathrm{~Hz}$ aromatic ring), 7.66 (s, 1H, aromatic ring).

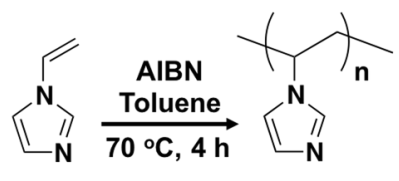

PVIm 
Poly(1-vinylimidazole) (PVIm). 1-vinylimidazole (5.0 g, $55 \mathrm{mmol}$ ) and 2,2'azobis(isobutyronitrile) (AIBN; $0.1 \mathrm{~g}, 0.6 \mathrm{mmol})$ were dissolved in toluene $(23 \mathrm{~mL})$. Nitrogen was bubbled into the solution for $20 \mathrm{~min}$. The polymerization was carried out at $70{ }^{\circ} \mathrm{C}$ for $4 \mathrm{~h}$ under nitrogen. After polymerization, the yellow precipitation was filtered off, and then the resulting solid was washed with acetone twice. The obtained product was dried in vacuum for $2 \mathrm{~h}$ to yield PVIm (3.5 g, conversion yield: $70 \%)$. ${ }^{1} \mathrm{H}$ NMR (400 MHz, $\left.\mathrm{D}_{2} \mathrm{O}\right): \delta=1.82-1.97$ (- $\mathrm{CH}_{2} \mathrm{CH}$-imidazole), 2.39-3.59 (- $\mathrm{CH}_{2} \mathrm{CH}-$ imidazole)), 6.49-6.91 (aromatic ring); ${ }^{13} \mathrm{C}-\mathrm{NMR}\left(100 \mathrm{MHz}, \mathrm{D}_{2} \mathrm{O}\right): \delta=40.3,40.5,40.7$, $51.2,52.1,52.3,53.7,117.5,128.5,128.9,129.3,136.9,137.1$. Viscosity-average molecular weight $\left(M_{\mathrm{v}}\right)$ : 40,000. $M_{\mathrm{v}}$ was calculated using the Mark-Houwink-Sakurada equation:

$$
[\eta]=K\left(M_{\mathrm{v}}\right)^{a}
$$

, where $[\eta]$, is the intrinsic viscosity, and $K$ and $a$ are constants, depending on the nature of the polymer and the solvent. We used the following data: $K=122 \times 10^{-3} \mathrm{~mL} \mathrm{~g}^{-1}$ and $a=0.51$ in $0.1 \mathrm{M} \mathrm{NaCl}$ at $25^{\circ} \mathrm{C}$, respectively. ${ }^{1}$
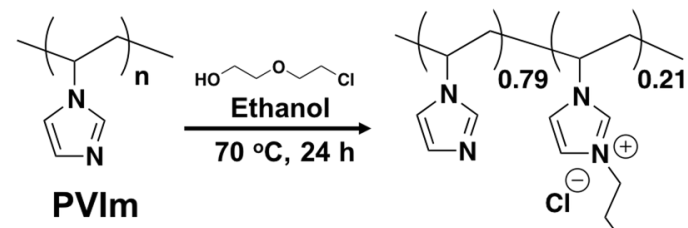

PVImQ

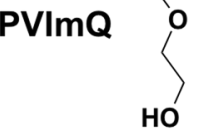

Partially quaternized PVIm (PVImQ). PVIm (0.12 g, $1.25 \mathrm{mmol}$ in the imidazole unit) and 2-(2-chloroethoxy)ethanol $(0.27 \mathrm{~mL}, 2.5 \mathrm{mmol})$ were dissolved in ethanol $(2.5$ $\mathrm{mL}$ ). Nitrogen was bubbled into the solution for $30 \mathrm{~min}$. The reaction mixture was stirred at $70^{\circ} \mathrm{C}$ for $24 \mathrm{~h}$ under nitrogen. The mixture was poured into ethyl acetate $(10$ $\mathrm{mL})$. The resulting precipitation was filtered off, and then was dried in vacuum to afford PVImQ (95 mg, conversion yield: $79 \%$ ). ${ }^{1} \mathrm{H}-\mathrm{NMR}\left(400 \mathrm{MHz}, \mathrm{D}_{2} \mathrm{O}\right): \delta=1.83-2.02(-$ $\mathrm{CH}_{2} \mathrm{CH}$ in the main chain), $3.03\left(\mathrm{CH}_{2} \mathrm{CH}\right.$ in the main chain), 3.45-3.81 (imidazolium$\mathrm{CH}_{2} \mathrm{CH}_{2} \mathrm{OCH} \mathrm{C}_{2} \mathrm{CH}_{2} \mathrm{OH}$ ), 6.49-7.14 (aromatic ring); ${ }^{13} \mathrm{C}-\mathrm{NMR}\left(100 \mathrm{MHz}, \mathrm{D}_{2} \mathrm{O}\right): \delta=$ 13.3, 14.1, 20.6, 40.5, 51.2, 52.4, 53.9, 60.3, 61.8, 66.1, 71.7, 117.0, 117.4, 117.7, $128.9,129.3,136.6,136.9,137.1$. 

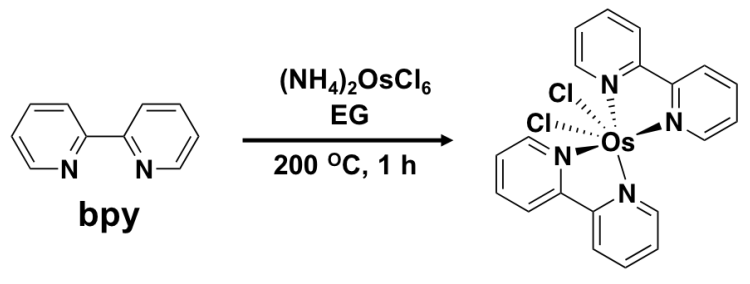

$\mathrm{Os}(\mathrm{bpy})_{2} \mathrm{Cl}_{2}$

Osmium bis(2,2'-bipyridine)chloride $\left(\operatorname{Os}(\mathbf{b p y})_{2} \mathbf{C l}_{2}\right)$. Ammonium hexachloroosmate(IV) (0.2 g, $0.45 \mathrm{mmol})$ and 2,2'-bipyridyl (bpy; $0.15 \mathrm{~g}, 0.9 \mathrm{mmol}$ ) were dissolved in ethylene glycol (EG; $7 \mathrm{~mL}$ ). Nitrogen was bubbled into the solution for $20 \mathrm{~min}$. The reaction mixture was stirred at $200{ }^{\circ} \mathrm{C}$ for $1 \mathrm{~h}$ under nitrogen. After cooling to $25^{\circ} \mathrm{C}$, the saturated aqueous solution of sodium dithionite $(7 \mathrm{~mL})$ was added to the resulting solution. The reaction mixtures were stirred at $0{ }^{\circ} \mathrm{C}$ for $30 \mathrm{~min}$. The purple-black precipitation occurred by reduction from Os(III) to Os(II). The precipitated product was filtered off, and then was washed with water and diethyl ether to yield Os(bpy) $)_{2} \mathbf{C l}_{2}\left(0.18\right.$ g, 70 \%). HRMS calcd. for $\mathrm{C}_{20} \mathrm{H}_{16} \mathrm{Cl}_{2} \mathrm{~N}_{4} \mathrm{Os}\left([\mathrm{M}]^{+}\right): 574.0342$, found: 574.0344 .

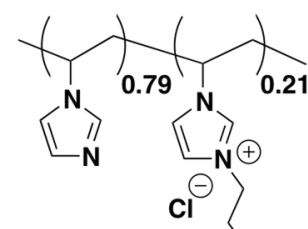

PVImQ

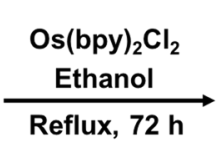

$\underset{\text { Reflux, } 72 \mathrm{~h}}{\mathrm{M}}$

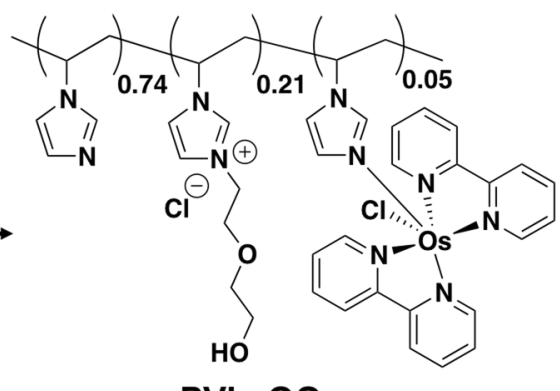

PVImQOs

Os complex-conjugated PVImQ (PVImQOs). A solution of Os(bpy) $\mathbf{C l}_{2}$ (50 mg, 0.013 $\mathrm{mmol})$ in ethanol (7.5 mL) was refluxed for $30 \mathrm{~min}$. PVImQ $(90 \mathrm{mg})$ in ethanol $(2.5 \mathrm{~mL})$ was added dropwise to the solution, and then the reaction mixture was refluxed for $72 \mathrm{~h}$. The resulting solution was poured into diethyl ether, and then the precipitated product was dried under vacuum to yield PVImQOs (87 mg, conversion yield: $97 \%$ ). ${ }^{1} \mathrm{H}-\mathrm{NMR}$ (400 MHz, $\left.\mathrm{D}_{2} \mathrm{O}\right): \delta=2.02$ (- $\mathrm{CH}_{2} \mathrm{CH}$ in the main chain), $3.04\left(\mathrm{CH}_{2} \mathrm{CH}\right.$ in the main chain), 3.48-4.19 (imidazolium- $\mathrm{CH}_{2} \mathrm{CH}_{2} \mathrm{OCH}_{2} \mathrm{CH}_{2} \mathrm{OH}$ ), 6.49-7.65 (aromatic ring); ${ }^{13} \mathrm{C}-\mathrm{NMR}$ (100 MHz, $\left.\mathrm{D}_{2} \mathrm{O}\right): \delta=11.6,14.1,14.2,16.8,17.3,38.5,40.5,40.7,51.9,57.4,57.6,60.2$, $60.4,66.1,67.5,71.7,112.9,117.4,123.4,127.1,128.8,129.3,136.8,150.7,160.3$. 


\section{Characterization}

The synthesized compounds were identified by means of ${ }^{1} \mathrm{H}$ and ${ }^{13} \mathrm{C}$ NMR spectroscopy (JNM-ECZ400R, JEOL Ltd., Tokyo, Japan), and high-resolution mass spectrometry (HRMS; QSTAR Elite, AB SCIEX, Framingham, MA, USA). Viscosityaverage molecular weight $\left(M_{\mathrm{v}}\right)$ was measured by viscometer (AR-G2, TA Instruments, New Castle, DE, USA).

Aqueous-dispersed SWCNTs were prepared using a tip-type ultrasonic homogenizer (Branson Sonifier 250, Branson Ultrasonics, Danbury, CT, USA; power output: $40 \mathrm{~W}$ ). Absorption spectra were measured using an ultraviolet-visible-near IR spectrophotometer (V-670, Jasco Co. Ltd., Tokyo, Japan).

Electrochemical properties were investigated using a potentiostat $(\mathrm{ALS} / \mathrm{CH}$ instruments Model 700C, BAS Inc., Tokyo, Japan); the working electrode: a gold disk electrode (AUE, $3 \mathrm{~mm}$ in diameter, $\mathrm{BAS}$ ), reference electrode: an $\mathrm{Ag} / \mathrm{AgCl}$ electrode (RE-1S, BAS), and a counter electrode: a platinum wire (Pt, $1 \mathrm{~mm}$ in diameter, BAS), respectively. The reference electrode was stored in the preservative vial (RE-PV, BAS) at $25^{\circ} \mathrm{C}$.

Surface behavior of composites was explored using scanning electron microscope (SEM; JSM6330F, accelerating voltage: $3 \mathrm{kV}$, JEOL). 


\section{Determination of the loading ratio of $\mathrm{Os}(\mathrm{bpy})_{2} \mathrm{Cl}_{2}$ in PVImQOs}

We prepared five different concentrations of $\mathbf{O s}(\mathbf{b p y})_{2} \mathbf{C l}_{\mathbf{2}}$ solutions in $\mathrm{MeOH}$ $(2.4,4.8,9.6,19.2$, and $38.3 \mu \mathrm{M}$, respectively). Absorption spectra showed the specific peak owing to the ligand-centered $\pi-\pi^{*}$ transition of the bipyridine group at $296 \mathrm{~nm}$. From Beer-Lambert law, the extinction coefficient of $\mathbf{O s}(\mathbf{b p y})_{\mathbf{2}} \mathbf{C l}_{\mathbf{2}}$ at $296 \mathrm{~nm}$ was estimated to be $26,220 \mathrm{M}^{-1} \mathrm{~cm}^{-1}$ with a coefficient of determination $R^{2}=0.998$.

PVImQOs exhibited absorbance of 0.4656 at $296 \mathrm{~nm}$ in $\mathrm{MeOH}(1 \mathrm{~mL})$ with a concentration of $50 \mu \mathrm{g} \mathrm{mL} \mathrm{m}^{-1}$. Because the concentration of $\mathbf{O s}(\mathbf{b p y})_{\mathbf{2}} \mathbf{C l}_{\mathbf{2}}(17.76 \mu \mathrm{M})$ was calculated from Beer-Lambert law, the amount of the Os complex was $10.19 \mu \mathrm{g}$. Therefore, the weight percentage of $\mathbf{O s}(\mathbf{b p y})_{2} \mathbf{C l}_{2}$ in PVImQOs was determined as follows:

$$
\frac{10.19}{50}=0.2038(w t \%)
$$

According to ${ }^{1} \mathrm{H}$ NMR spectra of PVImQ (Figure S13), the ratio of imidazole and imidazolium groups was 0.79:0.21. Since molecular weights of the imidazole and imidazolium groups are 94 and 183, the average molecular weight per unit in PVImQ was calculated the following equation:

$$
(94 \times 0.79)+(183 \times 0.21)=112.72
$$

We assumed that one $\mathbf{O s}(\mathbf{b p y})_{2} \mathbf{C l}_{\mathbf{2}}$ molecule (molecular weight: 574 ) is coordinated with $n$ repeated units of the average molecular weight per unit of PVImQ. We also considered that $Z$ is the total repeat unit of the average molecular weight per unit of PVImQOs. The weight percentage of $\mathbf{O s}(\mathbf{b p y})_{2} \mathbf{C l}_{2}$ in PVImQOs was estimated as follows:

$$
\begin{gathered}
\frac{574 Z}{(112.72 n+574) Z}=0.2038 \\
n=19.89
\end{gathered}
$$

We found that one $\mathbf{O s}(\mathbf{b p y})_{2} \mathbf{C l}_{\mathbf{2}}$ molecule was coordinated with about 20 repeated units of the average molecular weight per unit of PVImQ. Finally, the ratio of the coordinated Os(bpy $)_{2} \mathbf{C l}_{2}$ in PVImQOs was calculated using the following equation:

$$
\frac{1}{19.89}=0.05
$$


4. Absorption spectra of polymers and an Os complex in water

(a)

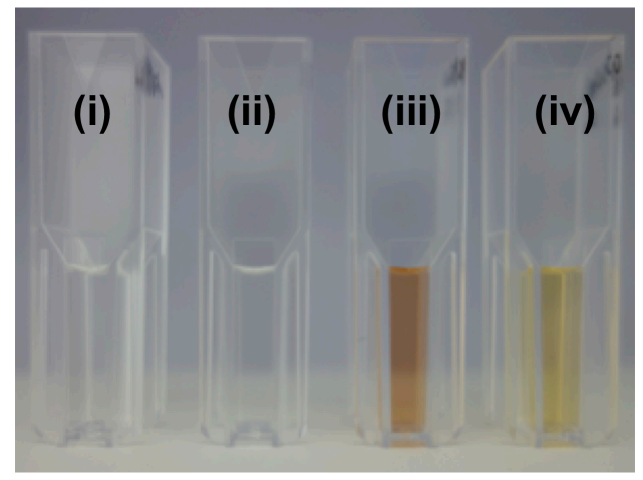

(b)

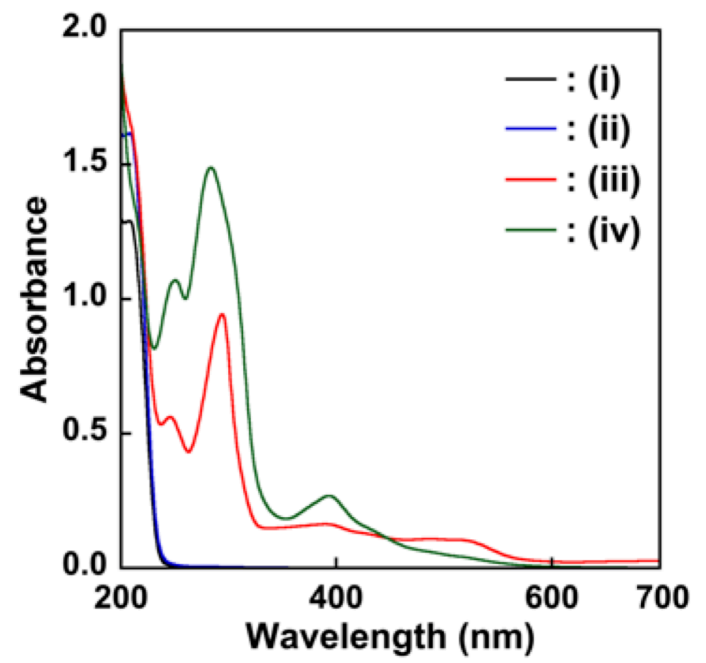

Figure S1. Photographs (a) and absorption spectra (b) of (i) PVIm, (ii) PVImQ, (iii) PVImQOs, and (iv) $\mathbf{O s}(\mathbf{b p y})_{2} \mathbf{C l}_{2}$ in water, respectively. Concentrations of all the solutions: $0.5 \mathrm{mg} \mathrm{mL}^{-1}$. 
5. Aqueous dispersion behavior of SWCNTs

(a)

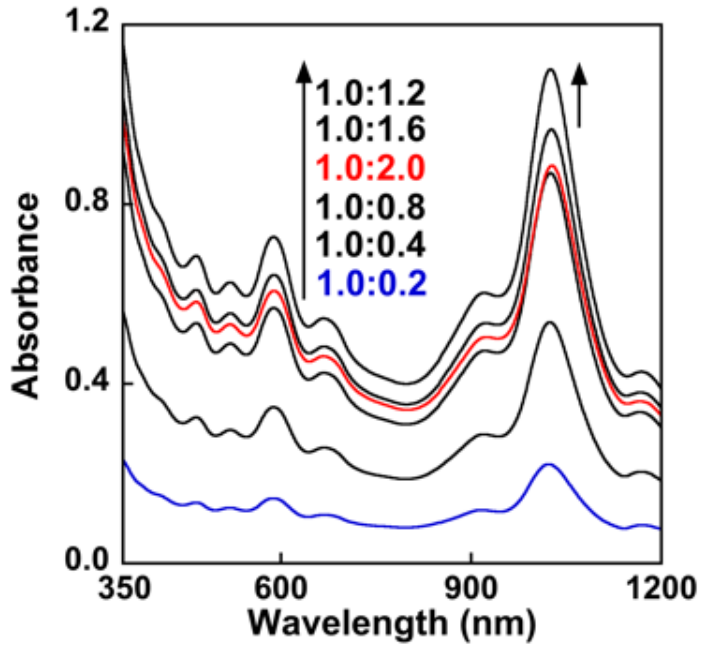

(b)

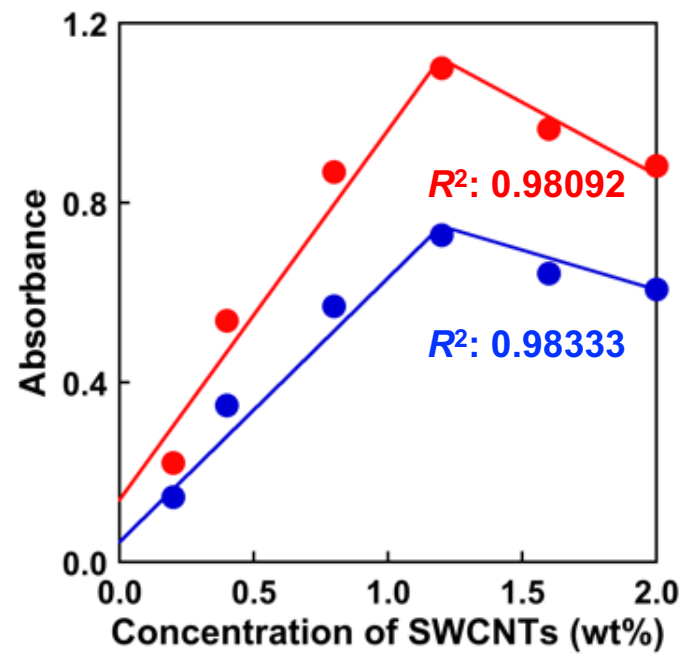

Figure S2. (a) Absorption spectra of PVImQ/SWCNTs composites in water at various concentrations of SWCNTs. (b) Absorbance at $588 \mathrm{~nm}$ (blue) and $1023 \mathrm{~nm}$ (red) as a function of the concentration of SWCNTs.

(i)

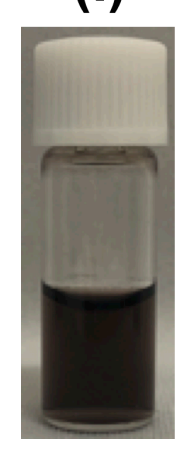

(ii)

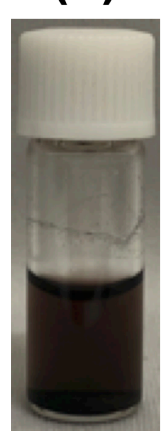

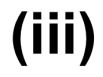

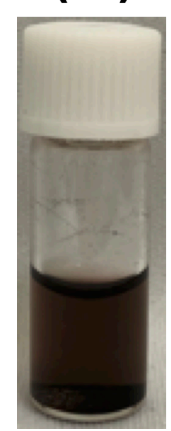

(iv)

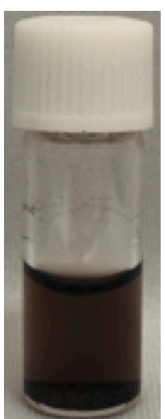

Figure S3. A dispersed solution of PVImQOs/SWCNTs (1.0:0.2 w/w) composite in water. (i) Just after dispersion, (ii) after one day, (iii) five days, (iv) seven days, respectively. 
6. Preparation of $\mathrm{GO}_{\mathrm{x}} / \mathrm{PVImQOs/SWCNTs} \mathrm{composites} \mathrm{on} \mathrm{the} \mathrm{working} \mathrm{electrode}$

(a)

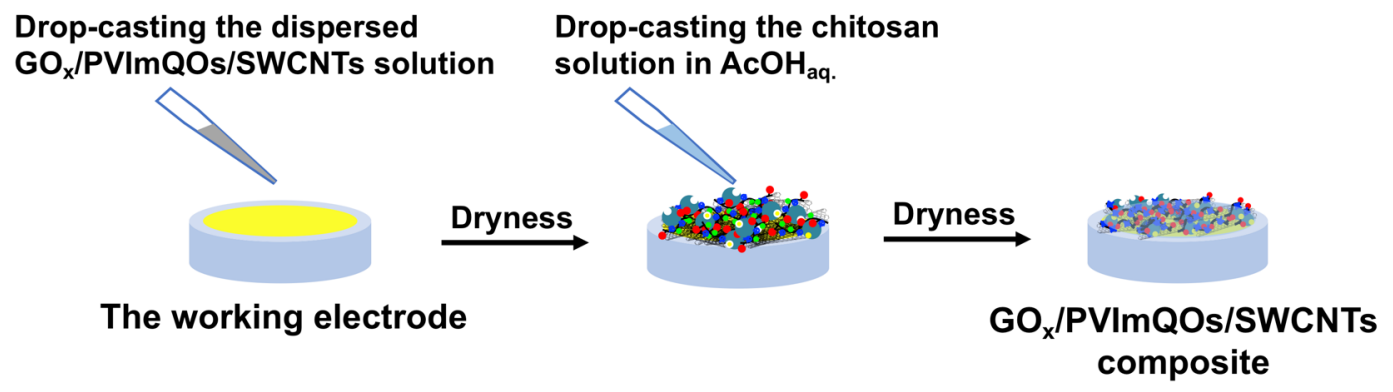

(b)

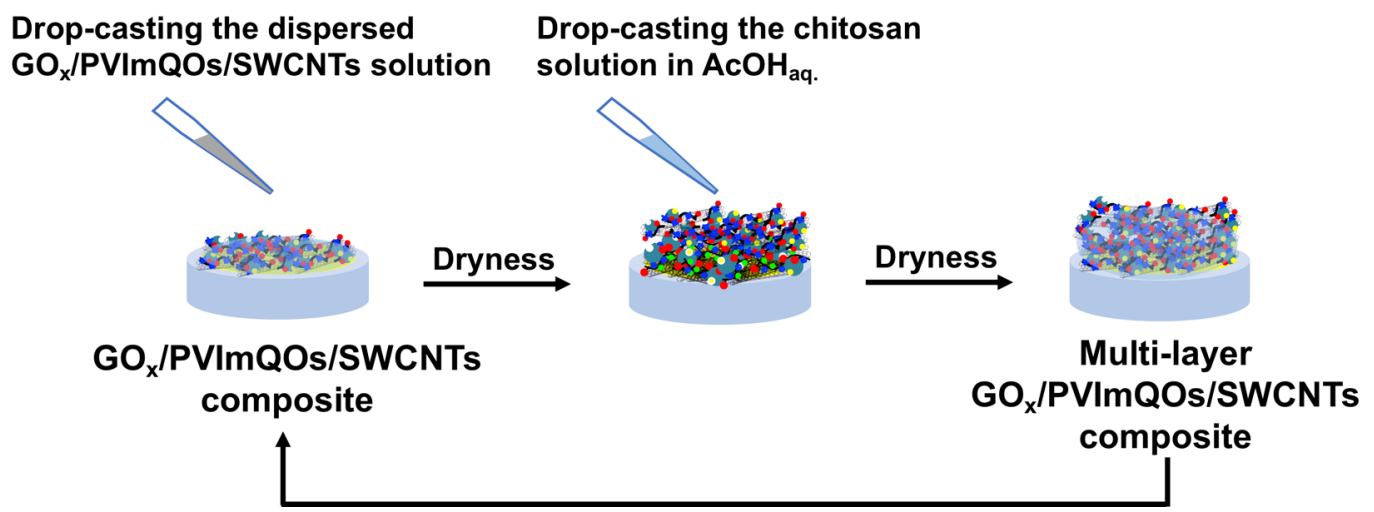

Figure S4. A solution-processed $\mathrm{GO}_{\mathrm{x}} / \mathbf{P V I m Q O s / S W C N T s ~ c o m p o s i t e ~ o n ~ t h e ~ w o r k i n g ~}$ electrode. (a) Single-layer, (b) multi-layer composites. 


\section{Determination of the loading amount of $\mathrm{GO}_{\mathrm{x}}$ using the Bradford assay ${ }^{2}$}

We prepared the $\mathrm{GO}_{\mathrm{x}}$ solution for the Bradford assay as follows:

$\mathrm{GO}_{\mathrm{x}}\left(5 \mathrm{mg} \mathrm{mL} \mathrm{mL}^{-1}\right)$ in phosphate buffer $(0.8 \mu \mathrm{L}, \mathrm{pH} 7.4)$ was diluted in phosphate buffer $(11 \mu \mathrm{L}, \mathrm{pH} 7.4)$ at $25^{\circ} \mathrm{C}$, yielding $11.8 \mu \mathrm{L}$ of the $\mathrm{GO}_{\mathrm{x}}$ solution. The $\mathrm{GO}_{\mathrm{x}}$ solution $(5$ $\mu \mathrm{L})$ was added to the Bradford reagent $(200 \mu \mathrm{L})$, affording the sample for the Bradford assay (Solution 1). BSA solutions including the Bradford reagent $(200 \mu \mathrm{L})$ were prepared at the various concentrations of BSA (from 0.1 to $0.5 \mathrm{mg} \mathrm{mL}^{-1}, 5 \mu \mathrm{L}$ per each) as standard solutions.

We found that absorbance at $595 \mathrm{~nm}$ for the Solution 1 is 0.296 . Linear relationships between absorbance at $595 \mathrm{~nm}$ and the concentration of BSA in the standard solutions were observed with coefficients of determination $\left(R^{2}\right) 0.9995$ (Figure S5). The concentration of $\mathrm{GO}_{\mathrm{x}}$ was determined by the following equation:

$$
\frac{0.296-0.185}{0.456}=0.243\left(m g m L^{-1}\right)
$$

Because we used the dispersed solution of $\mathrm{GO}_{\mathrm{x}} / \mathbf{P V I m Q O s / S W C N T s}(0.8: 1.0: 0.2$ $\mathrm{w} / \mathrm{w} / \mathrm{w})$ composite $(10 \mu \mathrm{L})$ for bioreactive behavior, the loading amount of $\mathrm{GO}_{\mathrm{x}}$ was estimated to be $2.43 \mu \mathrm{g}$.

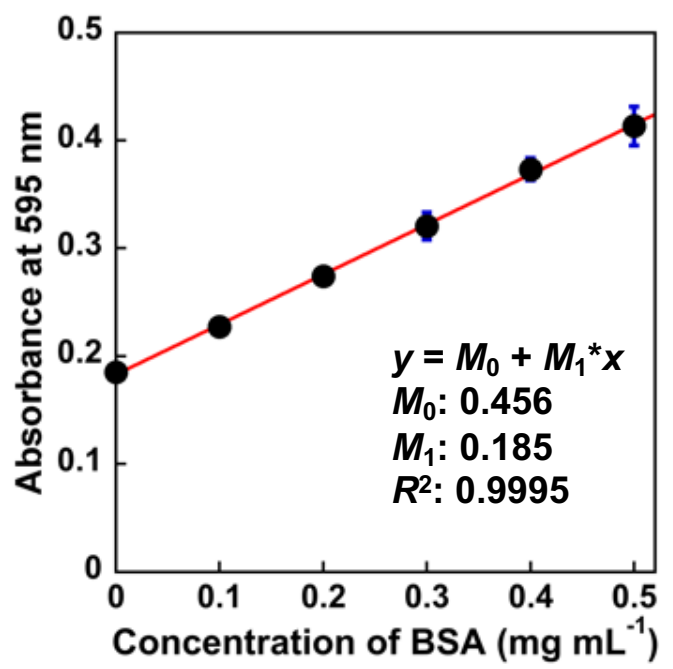

Figure S5. Relationships between absorbance at $595 \mathrm{~nm}$ and concentrations of BSA (11.8 $\mu \mathrm{L}, \mathrm{pH} 7.4)(n=3)$. 


\section{Electrochemical responses of enzyme/polymer/SWCNTs composites}

\subsection{Sample preparation}

Phosphate buffer (20 mM, pH 7.4) was prepared by mixtures of disodium hydrogen phosphate and sodium dihydrogen phosphate in deionized water. A stock solution of glucose (1M) was prepared in $20 \mathrm{mM}$ phosphate buffer. A stock solution of lactic acid (1M) was prepared using a similar method that described for the glucose solution. These solutions were stored at $4{ }^{\circ} \mathrm{C}$.

A solution containing diamond particles ( $6 \mu \mathrm{m}$ in diameter) was used for polishing the gold working electrode proper to amperometric measurements. The resulting electrode was rinsed with pure water, followed by polishing with alumina slurry (50 $\mathrm{nm}$ in diameter). Finally, the fresh working electrode was washed with pure water. $\mathrm{A} \mathrm{GO}_{\mathrm{x}} / \mathbf{P V I m Q O s / S W C N T s ~ c o m p o s i t e ~ w a s ~ p r e p a r e d ~ b y ~ d r o p - c a s t i n g ~ t h e ~}$ dispersed solutions $(10 \mu \mathrm{L})$ on the working electrode. The resulting electrode was dried under vacuum for $1 \mathrm{~h}$ at $25^{\circ} \mathrm{C}$. A LO $/$ PVImQOs/SWCNTs composite on the working electrode was prepared in a similar method that described for the $\mathrm{GO}_{\mathrm{x}} / \mathbf{P V I m Q O s / S W C N T s}$ composite.

\subsection{Experimental conditions}

Cyclic voltammogram was performed with potential range of -0.1 to $+0.6 \mathrm{~V}$ versus $\mathrm{Ag} / \mathrm{AgCl}$ at a scan rate of $5 \mathrm{mV} \mathrm{s}^{-1}$ in $20 \mathrm{mM}$ phosphate buffer ( $\left.\mathrm{pH} 7.4\right)$.

Amperometric response was investigated by the following protocols:

(i) Single-layer, two-layer, and four-layer $\mathrm{GO}_{\mathrm{x}} / \mathbf{P V I m Q O s / S W C N T s ~ c o m p o s i t e s ~}$ Electrolyte: $20 \mathrm{mM}$ phosphate buffer (pH 7.4)

Applied voltage: $+0.5 \mathrm{~V}$ versus $\mathrm{Ag} / \mathrm{AgCl}$

Concentrations of glucose

\begin{tabular}{|c|c|c|c|c|c|c|c|c|c|c|}
\hline Time (s) & 0 & 100 & 160 & 220 & 280 & 340 & 400 & 460 & 520 & 580 \\
\hline Concentration $(\mathrm{mM})$ & 0 & 0.5 & 1.0 & 2.0 & 4.0 & 8.0 & 10 & 20 & 40 & 80 \\
\hline
\end{tabular}

Interval for injection of glucose: $60 \mathrm{~s}$

(ii) $\mathrm{GO}_{\mathrm{x}} / \mathbf{P V I m Q O s / S W C N T s ~ c o m p o s i t e ~ b y ~ a d d i n g ~ c o l a ~ o r ~ d i e t ~ c o l a ~}$

Electrolyte: $20 \mathrm{mM}$ phosphate buffer (pH 7.4)

Applied voltage: $+0.5 \mathrm{~V}$ versus $\mathrm{Ag} / \mathrm{AgCl}$

The volume of cola or diet cola: $200 \mu \mathrm{L}$

Interval for injection: $60 \mathrm{~s}$ 
(iii) $\mathrm{LO}_{\mathrm{x}} / \mathbf{P V I m Q O s / S W C N T s ~ c o m p o s i t e ~}$

Electrolyte: $20 \mathrm{mM}$ phosphate buffer ( $\mathrm{pH}$ 7.4)

Applied voltage: $+0.5 \mathrm{~V}$ versus $\mathrm{Ag} / \mathrm{AgCl}$

Concentrations of lactic acid

\begin{tabular}{|c|c|c|c|c|c|c|c|c|}
\hline Time (s) & 0 & 100 & 160 & 220 & 280 & 340 & 400 & 460 \\
\hline Concentration (mM) & 0 & 0.25 & 0.5 & 0.75 & 1.0 & 2.0 & 3.0 & 4.0 \\
\hline
\end{tabular}

Interval for injection of lactic acid: $60 \mathrm{~s}$

\subsection{Electrochemical responses}

(a)

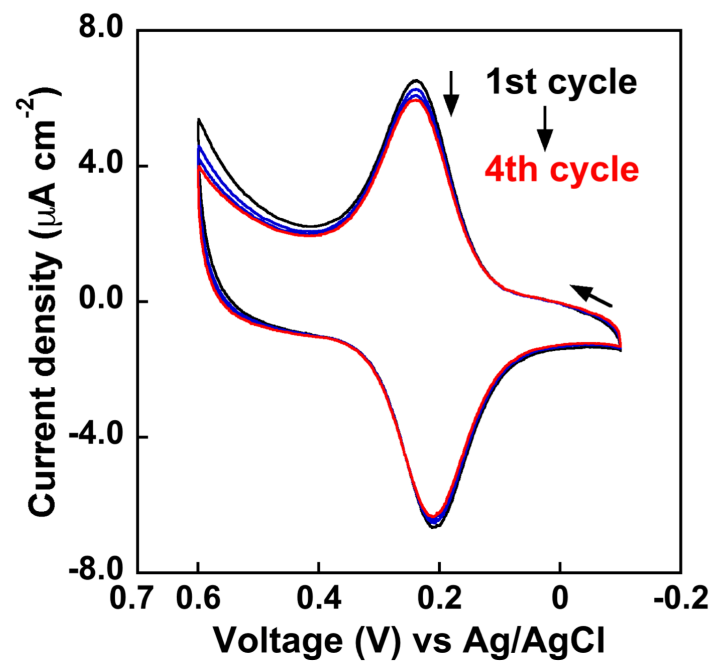

(b)

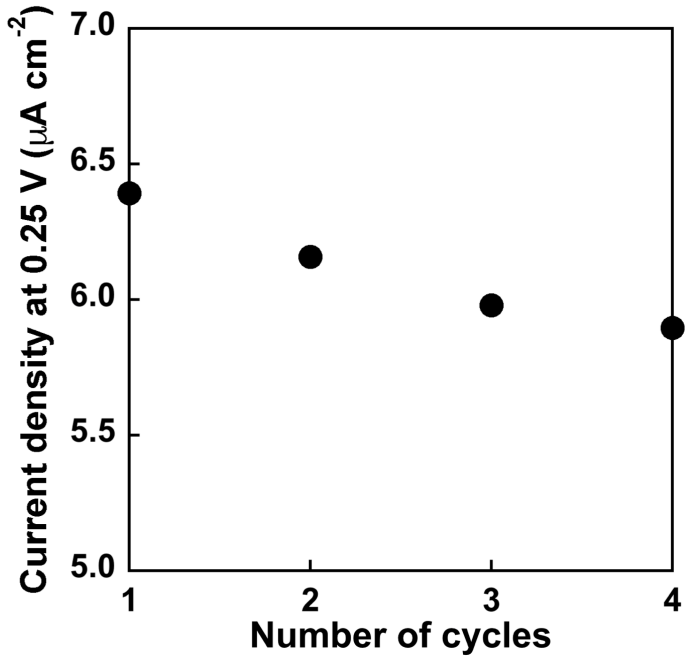

Figure S6. (a) Cyclic voltammograms of $\mathrm{GO}_{\mathrm{x}} /$ PVImQOs/SWCNTs (0.8:1.0:0.2

$\mathrm{w} / \mathrm{w} / \mathrm{w}$ ) composite without the chitosan layer in $20 \mathrm{mM}$ phosphate buffer ( $\mathrm{pH} 7.4)$. (b) Changes in current densities at an oxidation-reduction potential $E_{01 / 2}$ of $0.25 \mathrm{~V}$ versus $\mathrm{Ag} / \mathrm{AgCl}$. Scan rate: $5 \mathrm{mV} \mathrm{s}^{-1}$.

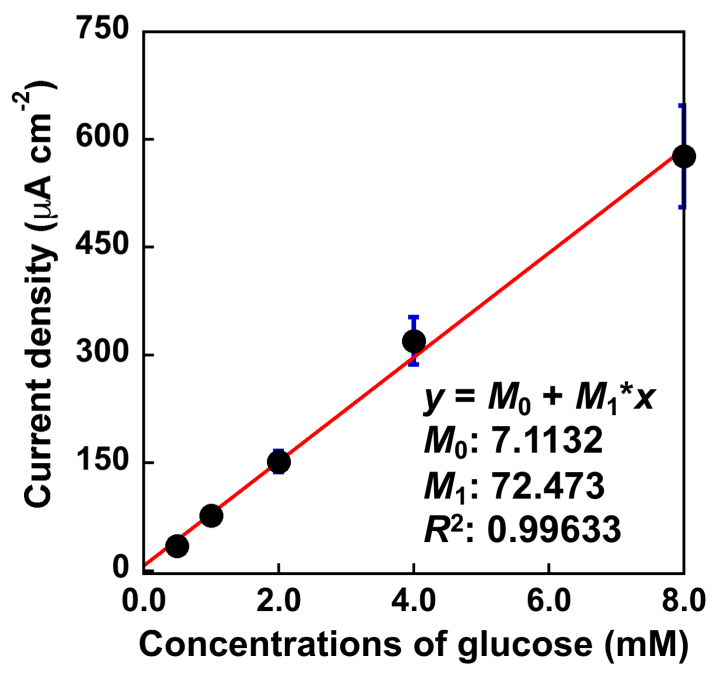

Figure S7. Relationships between current densities and concentrations of glucose in $\mathrm{GO}_{\mathrm{x}} / \mathbf{P V I m Q O s} / \mathrm{SWCNTs}(0.8: 1.0: 0.2 \mathrm{w} / \mathrm{w} / \mathrm{w})$ composite by adding 0.5-8.0 mM glucose in $20 \mathrm{mM}$ phosphate buffer $(\mathrm{pH} 7.4)$ at $0.5 \mathrm{~V}$ versus $\mathrm{Ag} / \mathrm{AgCl}$ on the working electrode. 
(a)

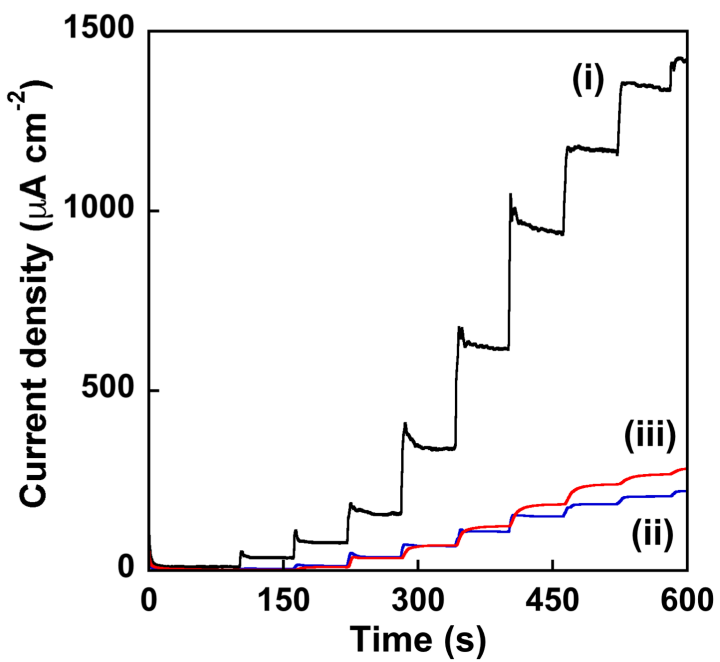

(b)

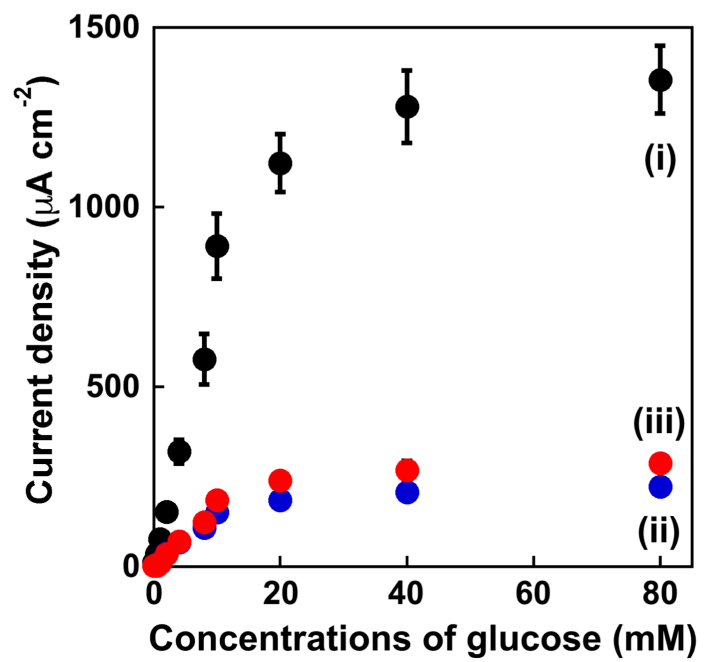

Figure S8. (a) Time-dependent amperometric responses of $\mathrm{GO}_{\mathrm{x}} / \mathbf{P V I m Q O s} / \mathrm{SWCNTs}$ (0.8:1.0:0.2 $\mathrm{w} / \mathrm{w} / \mathrm{w})$ composite at various numbers of active layers by adding $0.5-80$ $\mathrm{mM}$ glucose in $20 \mathrm{mM}$ phosphate buffer $(\mathrm{pH} 7.4)$ at $0.5 \mathrm{~V}$ versus $\mathrm{Ag} / \mathrm{AgCl}$ on a working electrode. (b) Relations between current densities and concentrations of glucose $(n=3)$. (i) Single-layer, (ii) two-layer, (iii) four-layer composites, respectively.

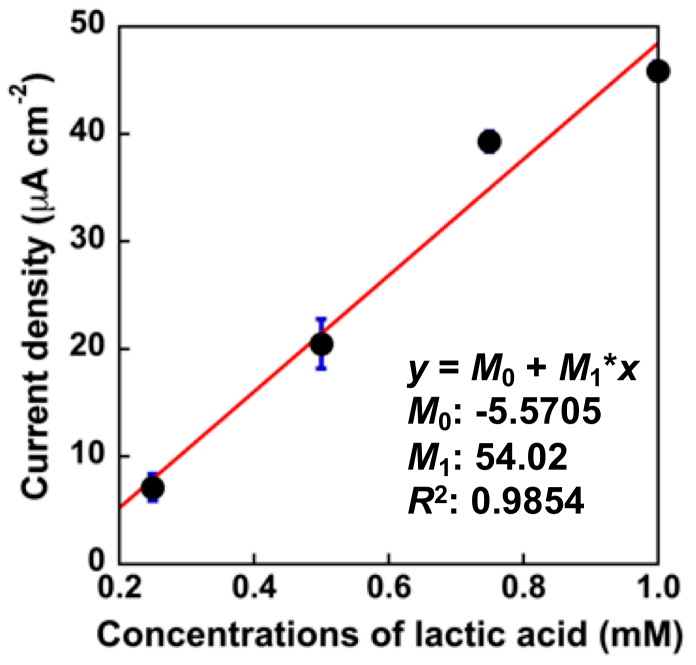

Figure S9. Relationships between current densities and concentrations of lactic acid in LO $_{\mathrm{x}} / \mathbf{P V I m Q O s / S W C N T s}(0.8: 1.0: 0.2 \mathrm{w} / \mathrm{w} / \mathrm{w})$ composite by adding $0.25-1.0 \mathrm{mM}$ lactic acid in $20 \mathrm{mM}$ phosphate buffer $(\mathrm{pH} 7.4)$ at $0.5 \mathrm{~V}$ versus $\mathrm{Ag} / \mathrm{AgCl}$ on the working electrode. 
(a)

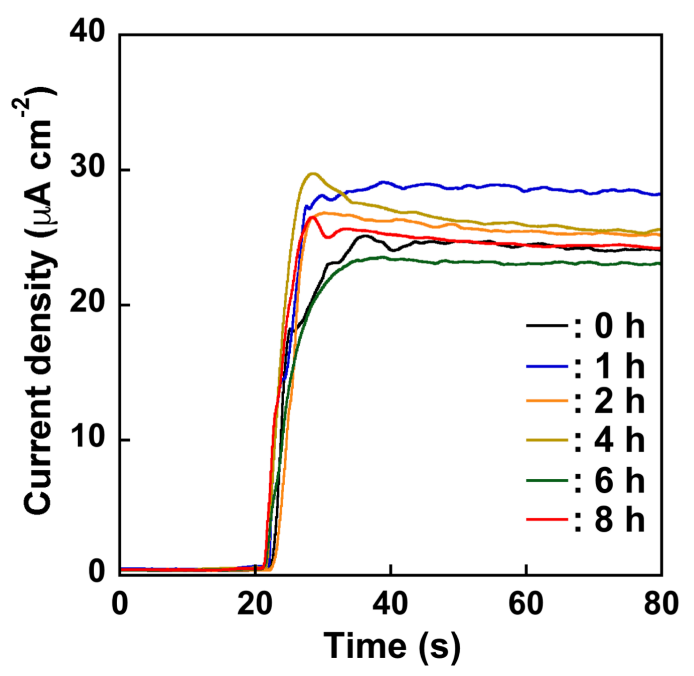

(b)

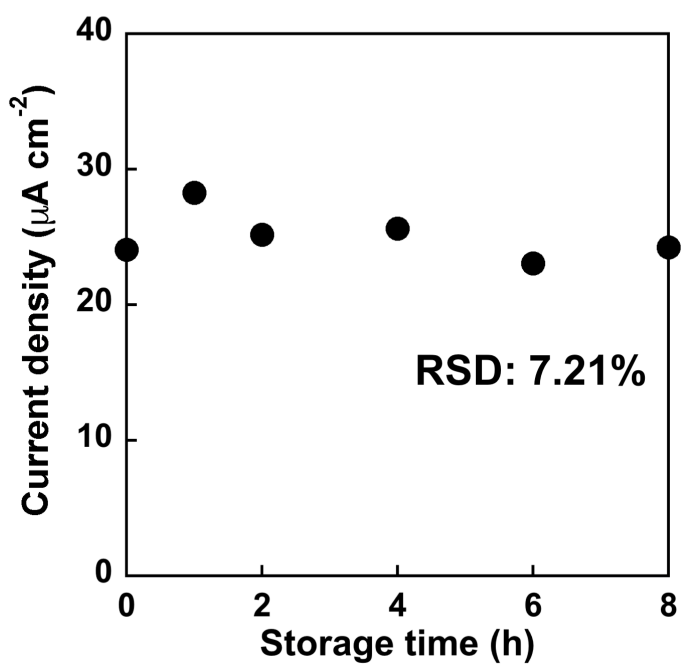

Figure S10. (a) Amperometic responses for $\mathrm{LO}_{\mathrm{x}} / \mathbf{P V I m Q O s / S W C N T s ~ ( 0 . 8 : 1 . 0 : 0 . 2 ~}$ $\mathrm{w} / \mathrm{w} / \mathrm{w}$ ) composite by adding $10 \mathrm{mM}$ lactic acid in $20 \mathrm{mM}$ phosphate buffer ( $\mathrm{pH} 7.4)$ at $0.5 \mathrm{~V}$ versus $\mathrm{Ag} / \mathrm{AgCl}$ at various storage times on the working electrode. (b) Current density at $0.5 \mathrm{~V}$ versus $\mathrm{Ag} / \mathrm{AgCl}$ as a function of storage time. Current densities were monitored after $80 \mathrm{~s}$ in Figure S10a. 


\section{Spectroscopic characterization}

\section{1. ${ }^{1} \mathrm{H}-\mathrm{NMR}$ spectra}

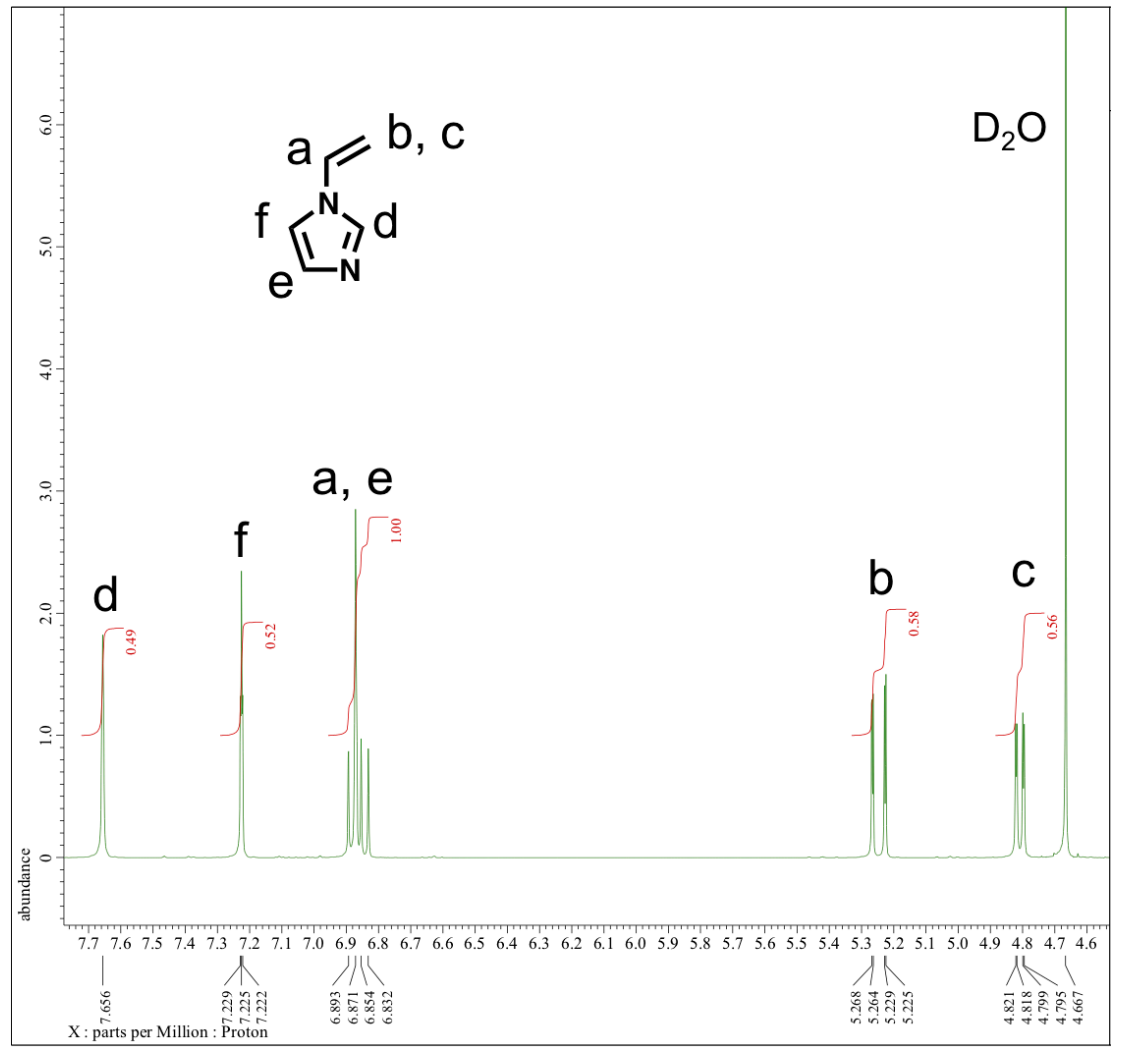

Figure S11. ${ }^{1} \mathrm{H}$ NMR spectra of 1-vinylimidazole in $\mathrm{D}_{2} \mathrm{O}$.

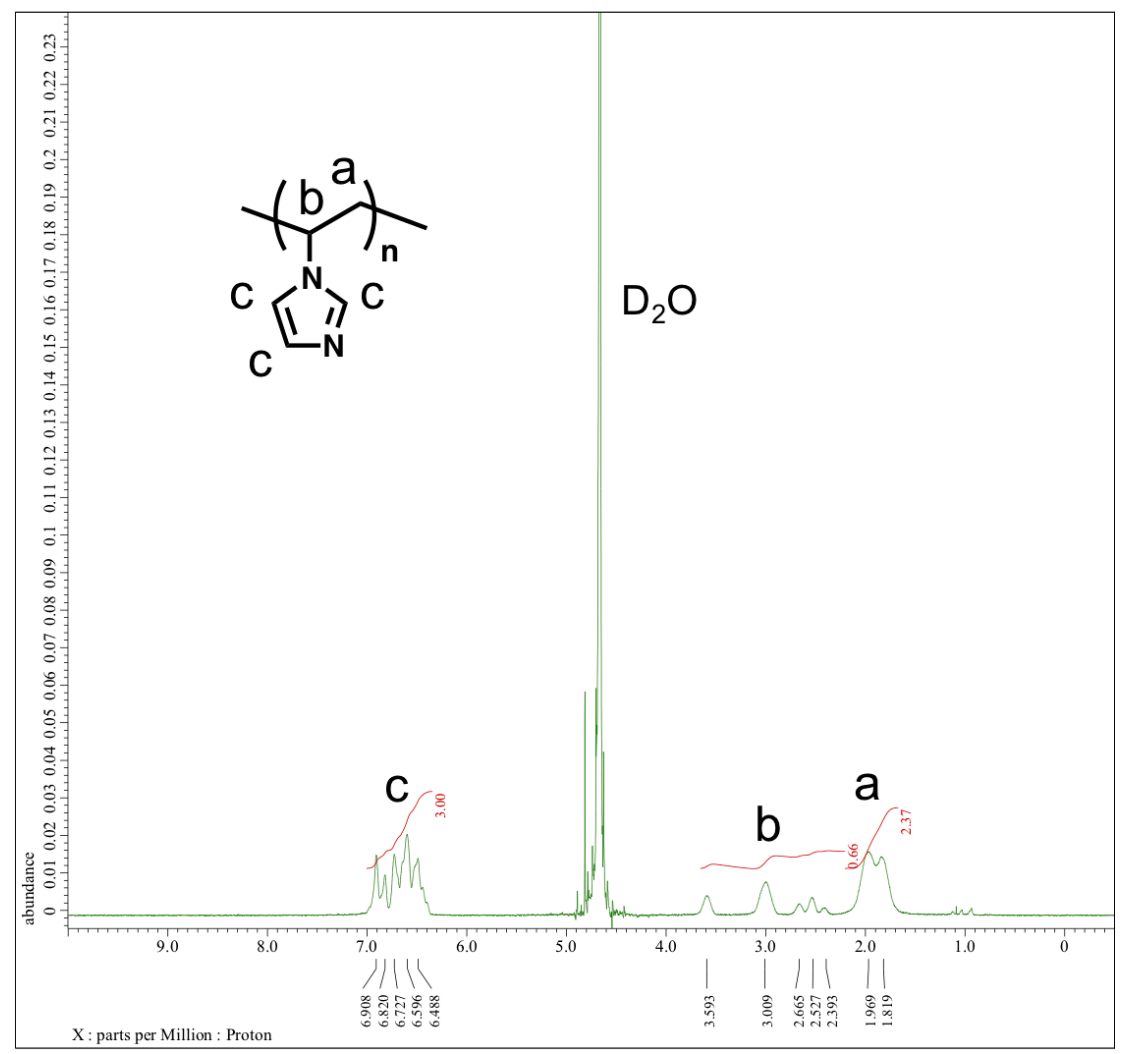

Figure S12. ${ }^{1} \mathrm{H}$ NMR spectra of PVIm in $\mathrm{D}_{2} \mathrm{O}$. 


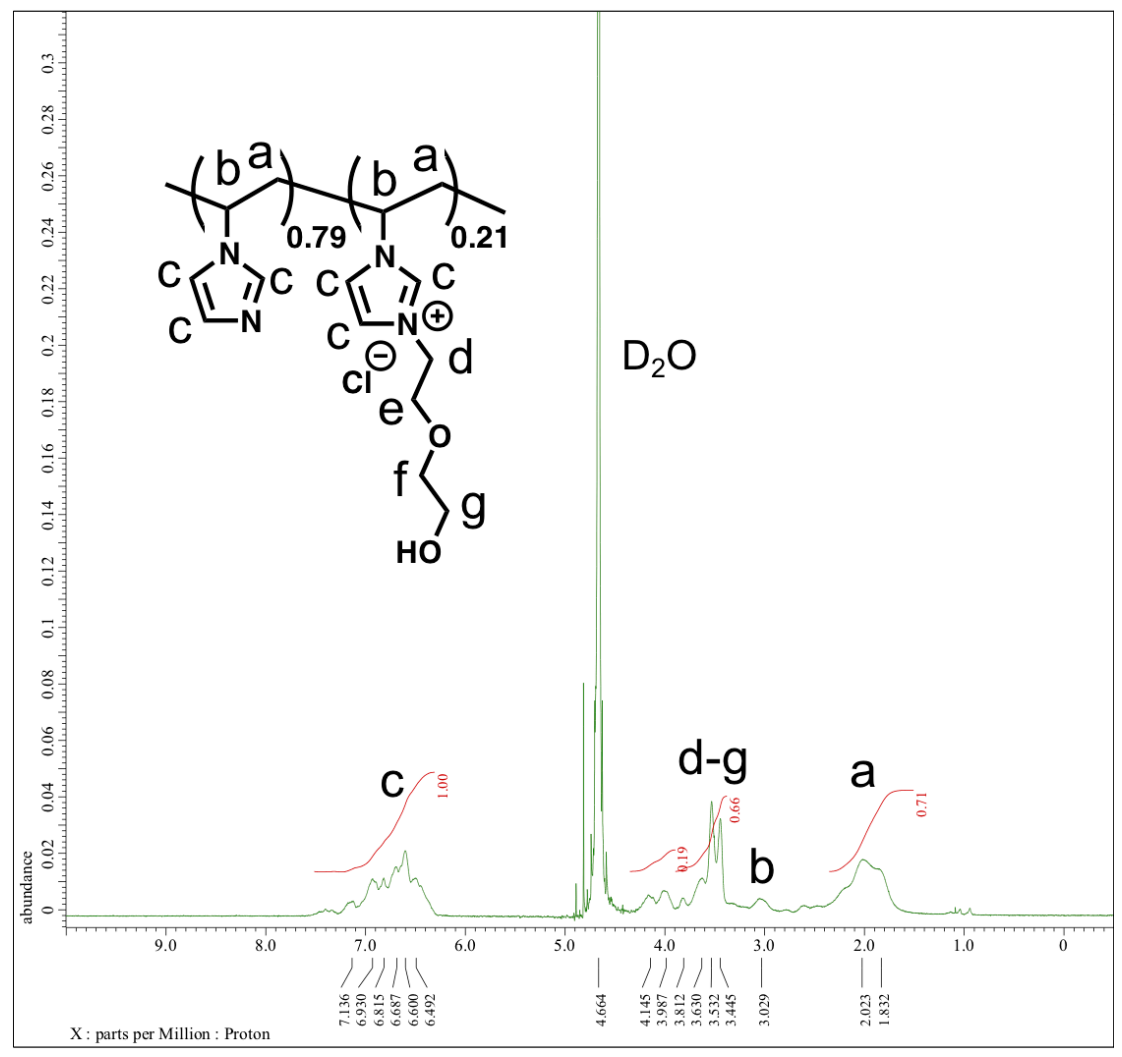

Figure S13. ${ }^{1} \mathrm{H}$ NMR spectra of PVImQ in $\mathrm{D}_{2} \mathrm{O}$.

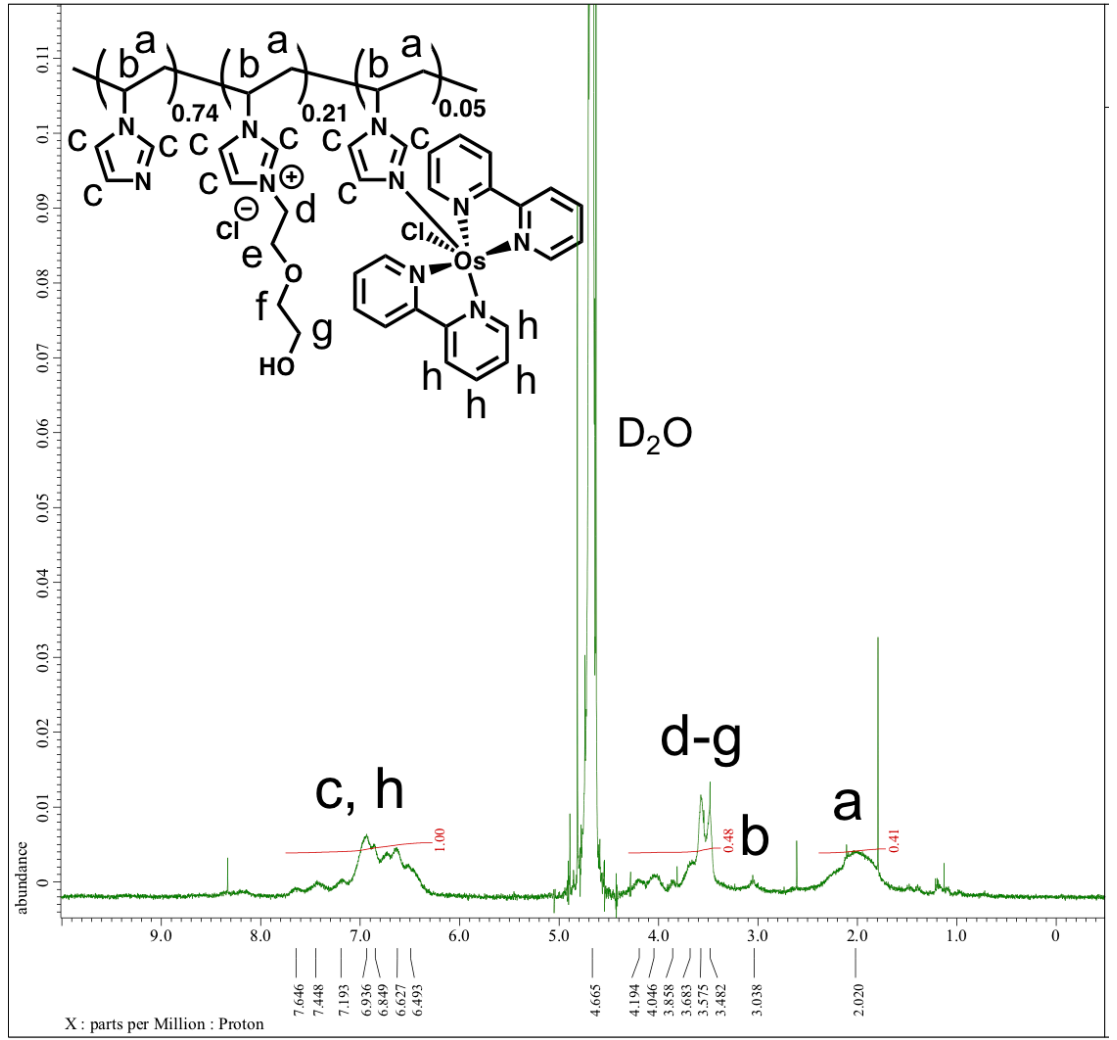

Figure S14. ${ }^{1} \mathrm{H}$ NMR spectra of PVImQOs in $\mathrm{D}_{2} \mathrm{O}$. 


\section{2. ${ }^{13} \mathrm{C}-\mathrm{NMR}$ spectra}

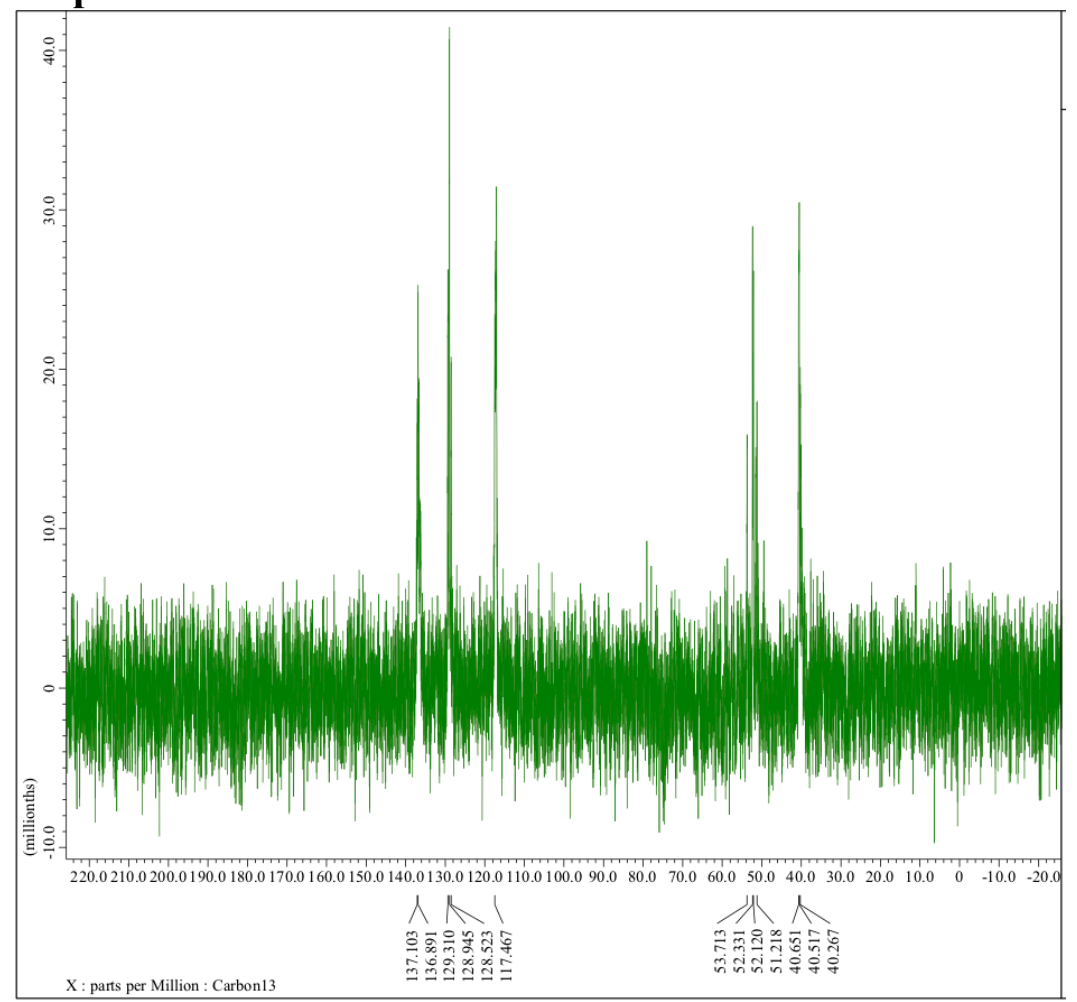

Figure S15. ${ }^{13} \mathrm{C}$ NMR spectra of PVIm in $\mathrm{D}_{2} \mathrm{O}$.

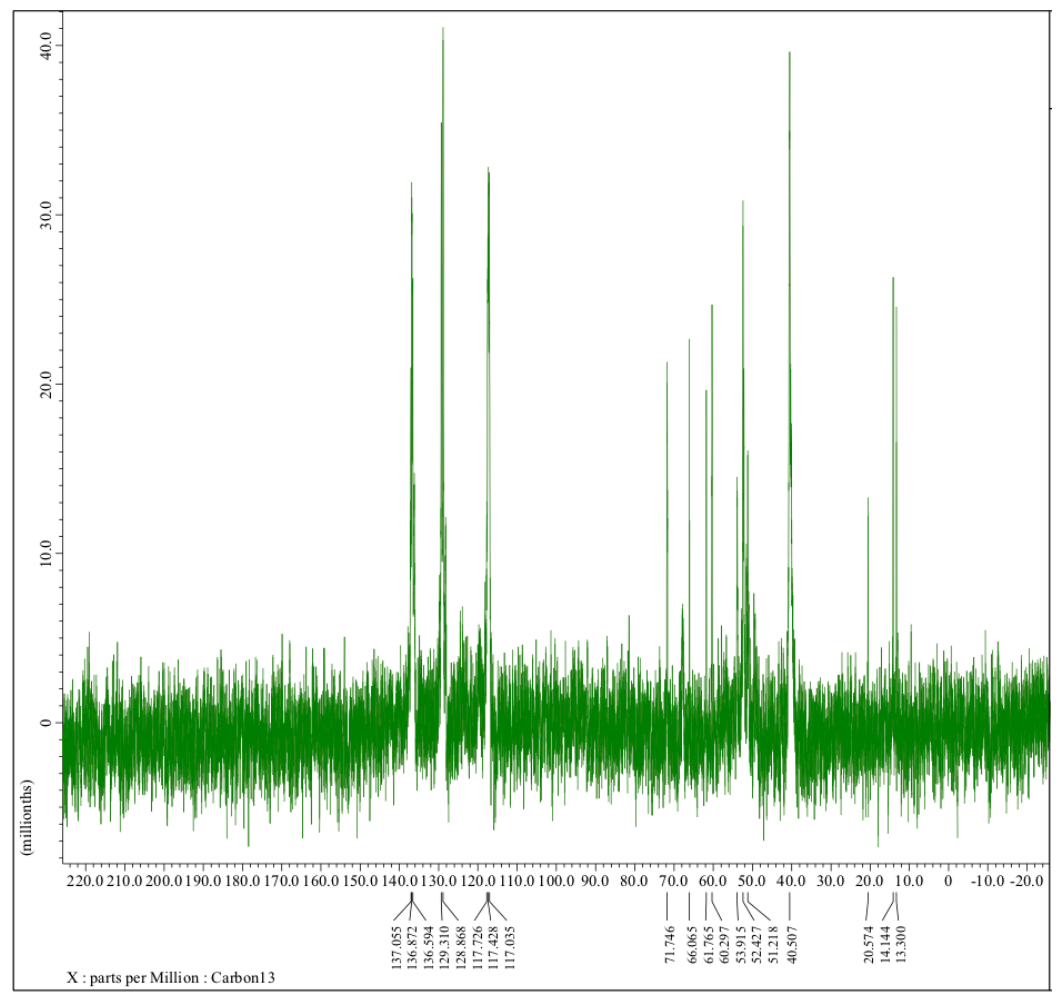

Figure S16. ${ }^{13} \mathrm{C}$ NMR spectra of PVImQ in $\mathrm{D}_{2} \mathrm{O}$. 


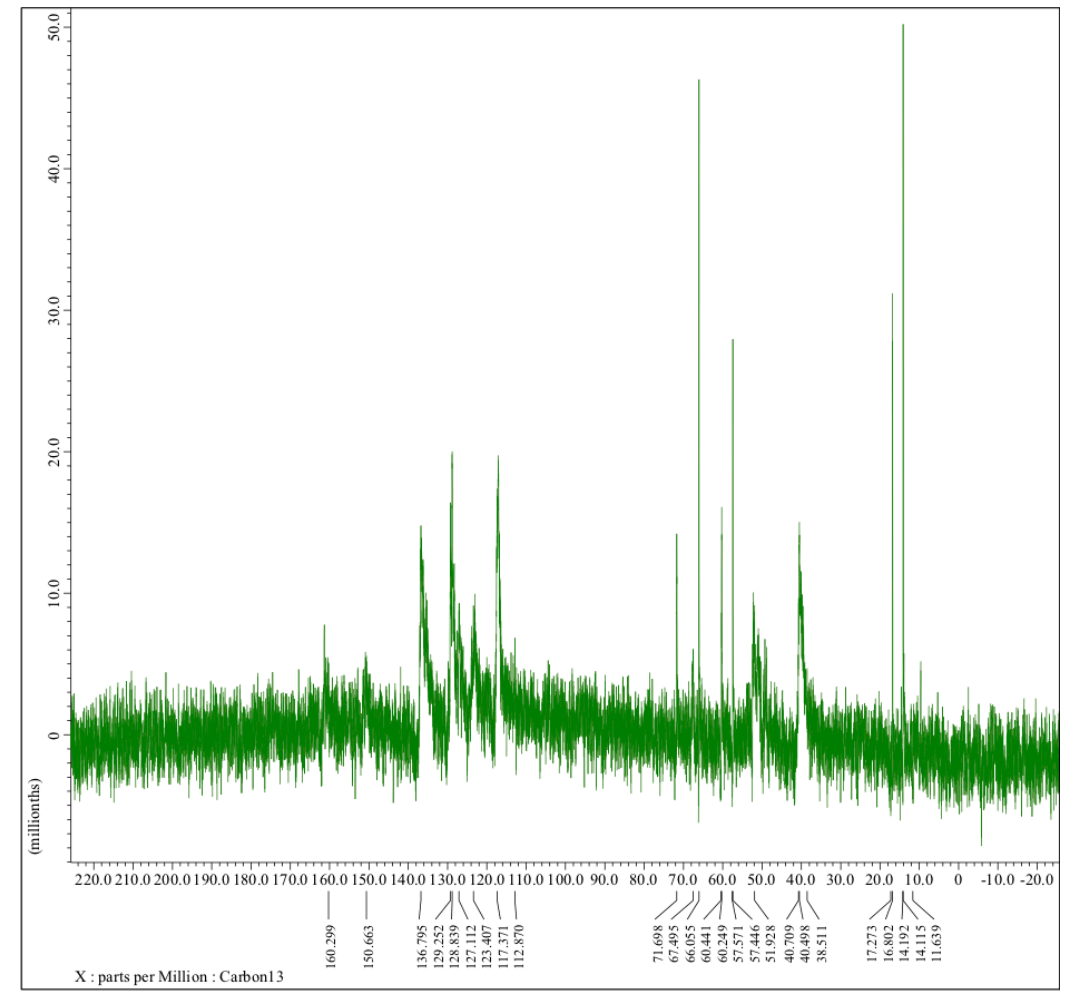

Figure S17. ${ }^{13} \mathrm{C}$ NMR spectra of PVImQOs in $\mathrm{D}_{2} \mathrm{O}$. 


\section{Supplementary references}

1. Brandrup, J.; Immergut, E. H.; Grulke, E. A., In Polymer Handbook, John Wiley \& Sons: 1999.

2. Bradford, M. M., A Rapid and Sensitive Method for the Quantitation of Microgram Quantities of Protein Utilizing the Principle of Protein-Dye Binding. Anal. Biochem. 1976, 72, 248-254. 